\title{
Association between spectator and other roles in school bullying
}

\author{
Marcela Almeida Zequinão ${ }^{1}$, Pâmella de Medeiros² ${ }^{2}$ Beatriz Pereira ${ }^{3}$, Fernando Luiz Cardoso ${ }^{4}$
}

DOI: http://dx.doi.org/10.7322/jhgd.122819

\begin{abstract}
:
Introduction: The school bullying is characterized by repetitiveness of aggression and the intentionality to injure or cause suffering to others. The bystanders to this phenomenon tend to be mainly responsible for the course that bullying will take and its results.

Objective: To analyse the association between the role of bystander with the other possible roles played in bullying.

Methods: A total of 409 children from the third to seventh grade participated in this study, with an average age of 11 years $(S D=1.61)$, enrolled in two municipal public schools in Florianópolis, Santa Catarina, Brazil. The instruments used were: one of the scales of the Questionnaire for the Study of Violence Among Peers, to identify bystanders, and the Olweus Questionnaire, to describe the possible roles played in school bullying.

Results: It was found that most of the participants assumed the role of bystander in school bullying. However, an association was found with regard to gender and being a bystander. Also, strong association was found between being a bystander and the other roles played in bullying, primarily in relation to the bullies.

Conclusion: These results reinforce the importance of bystanders in these aggressions, not only because they represent most of the participants, but mainly because of the positive or negative reinforcement they can offer in these aggressive behaviours. Therefore, the incentive and the encouragement of these students to denounce the aggressors, as well as defending the victims is essential to reduce school bullying.
\end{abstract}

Keywords: bullying, bystanders, vulnerability.

\section{INTRODUCTION}

Bullying is characterized by the repetition of aggression over time, with the intention of injuring or causing suffering to another and by the imbalance of power between the involved parties ${ }^{1}$. Bullying constitutes a social and group phenomenon, in which all the behaviours of the students involved, as well as the other members of the school community, exercise an effect on its genesis, maintenance and/or interruption.

Although several studies on the theme of bullying provide data only on school bullies and victims in relation to participation in this phenomenon, other researchers indicate this as a triadic social process, where the audi-

1 Doutoranda Estudos da Criança com especialização em Educação Física, Recreação, Lazer. Instituto de Educação, Universidade do Minho - IE/UM. Endereço: Rua: Dom Pedro V, no $2192^{\circ}$ Esquerdo Frente - Braga. CEP: 4710-057 - Portugal.

2 Mestranda do Programa de Pós-graduação em Ciências do Movimento Humano. Departamento de Ciências da Saúde da Universidade do Estado de Santa Catarina - UDESC. Endereço: Rua Paschoal Simone, n³58, Coqueiros - Florianópolis, CEP: $88080-350$ - Brasil.

3 Professora Doutora do Instituto de Educação da Universidade do Minho. Instituto de Educação, Universidade do Minho - IE/UM. Endereço: Campus Gualtar - Braga. CEP: 4710-070 - Portugal.

4 Professor Doutor dos Programas de Pós-graduação em Ciências do Movimento Humano e Pós-graduação em Educação da Universidade do Estado de Santa Catarina. Departamento de Ciências da Saúde da Universidade do Estado de Santa Catarina UDESC. Endereço: Rua Paschoal Simone, n³58, Coqueiros - Florianópolis, CEP: 88080-350 - Brasil.

Corresponding author: Marcela Almeida Zequinão - marcelazequinao@gmail.com

Suggested citation: Zequinão MA, Medeiros P, Pereira B, Cardoso FL. Association between spectator and other roles in school bullying. J Hum Growth Dev. 2016; 26(3): 352-359. Doi http://dx.doi.org/10.7322/jhgd.122819

Manuscript submitted: 04 Apr 2016, accepted for publication 14 May 2016. 
ence assumes an equal if not more important role than the others involved ${ }^{2-5}$. Bystanders tend to be mainly responsible for the course that the bullying will take, as well as what will be its respective outcomes ${ }^{6}$, given that when this group intervenes against a situation of violence, in general, it tends to quickly stop ${ }^{7}$.

Spectators constitute the largest group in bullying at school, and up to $68 \%$ of the students may be frequent observers of situations of harassment among peers ${ }^{8}$. In 2009, a survey conducted in Brazil identified widespread occurrence of such incidents, especially with regard to the testimony of bullying situations, since $70 \%$ of a group of 5,168 students reported having witnessed scenes of this phenomenon among peers ${ }^{9}$ This behaviour seems to be part of the daily life of most school-age children and adolescents. However, the attitude assumed towards this fact can decisively influence the intensity and the results of these aggressive behaviours experienced at school ${ }^{10}$. Data indicate that the spectators are reinforcing the behaviour of the aggressors ${ }^{11}$, due to the tendency to do nothing to protect the victims ${ }^{12}$. However, it should be noted also that these participants are affected directly by the occurrence of bullying, even when they are not directly involved in the assault. Many times the viewers feel guilty for not helping the victim and angry at themselves and the aggressors, in addition to feeling helpless, anxious, distressed and afraid of becoming targets when they observe any situation of harassment ${ }^{6,13}$. This makes them feel unsafe at school and can lead to them becoming distracted in class, damaging their school performance ${ }^{13}$. These consequences in the lives of bystanders may even be reflected in adulthood, resulting in the inability to solve problems assertively, having distorted visions of personal responsibility, a desensitization regarding antisocial acts and the dissemination of limits on acceptable behaviour ${ }^{13}$.

Considering that bullying is a type of aggression that is imperceptible to adults, the role of the spectator becomes even more relevant. However, little is known about the relationship between this role and other possible roles undertaken by children and adolescents in relation to bullying (victim, perpetrator and victim-offender). Therefore, it is essential to identify whether the bystander also takes on other roles in this phenomenon in order to determine the best intervention strategies with this group. Thus, the objective of this study is to analyse the association between the role of the bystander with the other possible roles of participating in bullying.

\section{METHODS}

\section{Characterization of the research}

A cross-sectional study of a descriptive nature and intentional sampling was conducted in the metropolitan region of Florianópolis, State of Santa Catarina, in southern Brazil, between February and December 2012. Prior to data collection, the parents, the children and adolescents received detailed information about the research. Only students who expressed a willingness to cooperate with the investigation and presented a signed an informed consent participated in this study. All participants were present at data collection. Participants answered both self-applied questionnaires, of their own experience as a spectator and other roles in bullying.

The selection of the participating schools was intentional because it was the indication of the Education Department of the municipality, in which the selected schools were fit the most infitted best the profile proposed by the wide broad project. After this selection, all students of the third to seventh grades were invited to participate in the study. However, only those who delivered the informed consent signed by parents were selected. The only criterion of exclusion adopted in recruitment of participants was if they presented with some intellectual disabilities that prevented their understanding of instruments, based on the indication of School Attendance (SA).

The participants of this study were children and adolescents from the 3rd third to the 7thseventh grades of Elementary School, of both genders, enrolled in the current period of study in two municipal public schools. According to the project's objectives, to of which this study is a part, a sample size was calculated assuming an alpha of 0.05 and power of $50 \%$. Based on the sample calculation the minimum expected were 316 participants, but the final sample size was 409 participants. In terms of characterization, the age of participants was between 8 and 16 years, with an average of 11.1 years for boys $(n=207)$ and 10.9 years for girls $(n=202)$. That This can be explained by the fact that most belonged to the more advanced grades, referring to the sixth and seventh grades (52.8\%), as well as the fact that many participants had already failed a year in school (48.5\% of boys and $40.0 \%$ of girls). Regarding skin colour, the boys stated they were Caucasian (68.6\%), Black (25.6\%) or Brown (5.8\%). Girls stated they were Caucasian (73.3\%), Black (24.7\%) or Brown (2.0\%).

This research is part of a broad project approved by the Committee of Ethics in research with humans from a public university of the State of Santa Catarina (5439/2011 Process).

\section{Instruments}

In this study one of the scales of the Questionnaire for the Study of Violence Among Peers was used ${ }^{12}$. This scale is present in the fourth part of the instrument, and consists of 15 objective questions pertaining to being a spectator of bullying. The first 13 questions are answered by a Likert scale of 1 to 5 , where $1=$ never, $2=$ not a lot, 3 = sometimes 4 = often, 5 = always. With the sum of points of all issues, each participant obtained a score for participation in school bullying as spectators. The last two questions are related to where the attacks occur and to the attitudes taken by spectators when they watched someone beat or harass a colleague on the way to school. From this range the spectator role was defined through the ROC (Receiver Operating Characteristic) curve. The data pointed area value of $=0.768$ and $p=0.0001$, with sensitivity equal to $83.2 \%$ and specificity equal to $57.3 \%$, resulting in a cut-off point $>29.0$ points in the sum of questions about being a spectator. Regarding internal reliability, the Questionnaire for the Study of Violence Among Peers showed a good level of internal consistency, with a Cronbach's alpha of 0.829 . 
To describe the possible roles of participation in bullying two issues from the Olweus' survey ${ }^{14}$ were used. The first question asked how many times, in the past three months, the participant had been the victim of bullying at school, while the second asked how many times the participant had been the aggressor. With the information obtained through those who replied that they were victims and aggressors three or more times, a 'victim-offender' variable, was created, classifying them into four categories of participation in bullying: 'not participating', 'victim', 'assailant' and 'victim-offender'. The Olweus survey also showed a good level of internal consistency, with a Cronbach's alpha of equals 0.750 .

\section{Analises of the data}

Initially, an exploratory analysis of the data was carried out in order to summarize the information obtained in the study. The qualitative variables were described in terms of absolute frequency and percentage, since quantitative variables are described by mean and standard deviation. The inferential statistics was performed by chi-square tests, to verify the association between the variables; Spearman's correlation was used to verify the relationship between variables; Mann-Whitney and Kruskal-Wallis tests for comparison between groups; and receiver operating characteristics curve (ROC Curve, to identify the change in sensitivity and specificity for different cut-off values. In this case, the reference variable was 'had to endure or not any aggression from the classmates at school' (first issue of scale of bystanders, with an area under the curve value in excess of 0.5 .

The research data were tabulated and analysed on the computer program Statistical Package for the Social Science (SPSS for Windows) version 20.0, and for all tests a confidence interval of $95 \%$ ( $\mathrm{p}<0.05$ ) was adopted. In addition, the following programs were used: BioEstat version 5.0, for post hoc Dunn, in the analysis of variance of the Kruskal-Wallis test; and MedCalc version 12.6, to identify the value in ROC curve.

\section{RESULTS}

It was found that $56.5 \%$ of the boys and $62.4 \%$ of the girls were considered spectators, but when not separated by gender this number changed to $59.4 \%$ of students: no association was found with regard to gender and being a spectator (Table 1 ).

As for aggression observed by the students, it was identified that making jokes about peers, calling them ugly or other offensive names and gossiping were the types of bullying most prevalent for both genders, according to bystanders. Among all the questions, it was found that the only kind of aggression seen by spectators that presented different results between genders was group exclusion, in which girls had observed this kind of behaviour more than boys (Table 2).

Table 1: Role in bullying at school in being or not being a spectator

\begin{tabular}{|c|c|c|c|c|c|c|}
\hline $\begin{array}{l}\text { BEING } \\
\text { A BULLYING } \\
\text { SPECTATOR }\end{array}$ & $\mathbf{N}$ & $\%$ & GIRLS & $\%$ & $\chi^{2}$ & p \\
\hline Not spectator & 90 & 43.5 & 76 & 37.6 & & \\
\hline Spectator & 117 & 56.5 & 126 & 62.4 & 1.453 & 0.228 \\
\hline Total & 207 & 100 & 202 & 100 & & \\
\hline
\end{tabular}

$\mathrm{N}$ : number of participants; $\chi^{2}$ : Qui-square; $\mathrm{p}<0.05$.

Table 2: Aggression types observed by the spectators of bullying in both genders

\begin{tabular}{|c|c|c|c|c|c|c|}
\hline \multirow{2}{*}{$\begin{array}{l}\text { VARIABLE } \\
\text { HAVE YOU SEEN SOMEONE... }\end{array}$} & \multicolumn{2}{|c|}{$\begin{array}{c}\text { BOYS } \\
(N=207)\end{array}$} & \multicolumn{2}{|c|}{$\begin{array}{c}\text { GIRS } \\
(N=202)\end{array}$} & \multirow[b]{2}{*}{$U$} & \multirow[b]{2}{*}{$\mathrm{p}$} \\
\hline & $\mathrm{X}$ & $\mathrm{SD}$ & $\mathrm{X}$ & SD & & \\
\hline Aggress someone in the last two weeks & 1.27 & 0.74 & 2.16 & 1.27 & 19453.00 & 0.171 \\
\hline Push with violence & 1.57 & 0.86 & 3.07 & 1.29 & 20814.50 & 0.936 \\
\hline Threaten verbally & 1.39 & 0.81 & 2.67 & 1.41 & 20517.00 & 0.729 \\
\hline Make jokes about peers & 2.11 & 1.03 & 3.62 & 1.25 & 19338.00 & 0.179 \\
\hline Physically hit & 1.55 & 0.88 & 2.75 & 1.29 & 20595.00 & 0.786 \\
\hline Call offensive names & 2.33 & 1.22 & 3.86 & 1.22 & 19374.00 & 0.188 \\
\hline Gossip & 2.16 & 1.09 & 3.81 & 1.24 & 18846.00 & 0.077 \\
\hline Delete from the group & 1.57 & 0.86 & 3.10 & 1.48 & 16912.50 & 0.001 \\
\hline Steal things from others & 1.15 & 0.43 & 1.93 & 1.28 & 20766.50 & 0.886 \\
\hline Do things on purpose to hurt someone & 1.47 & 0.78 & 2.76 & 1.24 & 20708.00 & 0.862 \\
\hline Damage the peers' clothes on purpose & 1.11 & 0.43 & 1.54 & 1.07 & 19569.50 & 0.104 \\
\hline Move the hand over someone's body & 1.14 & 0.47 & 2.09 & 1.34 & 19720.00 & 0.237 \\
\hline Hit or run after someone in the way to school & 1.34 & 0.67 & 2.28 & 1.39 & 19122.00 & 0.117 \\
\hline
\end{tabular}

$\mathrm{N}$ : number of participants; $\mathrm{X}$ : average; SD: standard deviation; U: Mann-Whitney; $\mathrm{p}<0.05$. 
Those who reported ever having seen anyone beating or chasing a peer on the way to school were asked what was the attitude taken in the face of such situations of bullying. The data indicate that most students, both boys and girls, did nothing to stop such attacks. Others came to watch these violent situations, while the most common aid methods used were supporting the assaulted and looking for an adult (Table 3).

Regarding the possible association between being or not being a spectator and playing a participating role in bullying, there was a strong association found between these variables, indicating that being a spec- tator of bullying is associated with the roles assumed in this phenomenon, but mostly in relation to offenders (Table 4).

The differences between attacks watched by spectators and the roles of participating in bullying at school were analysed. It was observed that the main differences occur between the group that does not participate and the victims, the victims being the biggest audience in almost all cases. However, the variables 'beat physically' and 'damage the clothes on purpose' had a value of $\mathrm{p}<0.05$, but the differences between the groups were not sensitive to Post Hoc Dunn (Table 5).

Table 3: Attitudes of spectators of both genders with the situation of having already seen anyone hit or pursue a peer on the way to school

\begin{tabular}{|c|c|c|c|c|}
\hline \multirow[t]{2}{*}{ What do you do? } & \multicolumn{2}{|c|}{$\begin{array}{c}\text { BOYS } \\
(115)\end{array}$} & \multicolumn{2}{|c|}{$\begin{array}{c}\text { GIRLS } \\
\text { (93) }\end{array}$} \\
\hline & $\mathbf{N}$ & $\%$ & $\mathbf{N}$ & $\%$ \\
\hline Nothing & 39 & 33.0 & 31 & 34.0 \\
\hline Ran away/ had fear & 6 & 5.0 & 10 & 11.0 \\
\hline Resorted an adult & 12 & 10.0 & 12 & 13.0 \\
\hline Asked to the aggressor to stop & 10 & 9.0 & 4 & 4.0 \\
\hline I approached to see & 17 & 15.0 & 15 & 16.0 \\
\hline Counselled to stay far from the aggressor & 2 & 2.0 & 4 & 4.0 \\
\hline Laughed & 2 & 2.0 & 1 & 1.0 \\
\hline Supported the victim & 18 & 15.0 & 14 & 15.0 \\
\hline Separated & 9 & 8.0 & 2 & 2.0 \\
\hline
\end{tabular}

$\mathrm{N}$ : number of participants.

Table 4: Association between being or not being a spectator and the other roles of bullying participation

\begin{tabular}{lcccccccccc} 
Being a spectator & \multicolumn{2}{c}{ DOES } & \multicolumn{2}{c}{ VICTIM } & \multicolumn{2}{c}{ AGGRESSOR } & \multicolumn{2}{c}{$\begin{array}{c}\text { VICTIM- } \\
\text { AGGRESSOR }\end{array}$} & $\chi^{2}$ & p \\
& PARTICIPATE & N & $\%$ & N & $\%$ & N & $\%$ & N & $\%$ & \\
No & 134 & 48.7 & 17 & 25.4 & 6 & 18.8 & 6 & 31.6 & 20.690 & 0.001 \\
Yes & 141 & 51.3 & 50 & 74.6 & 26 & 81.2 & 13 & 68.4 & & \\
Total & 275 & $100 \%$ & 67 & $100 \%$ & 32 & $100 \%$ & 19 & $100 \%$ & \\
\hline
\end{tabular}

Table 5: Differences between aggression assisted by bystanders and the roles of participation in school bullying

\begin{tabular}{|c|c|c|c|c|c|c|c|c|c|c|}
\hline \multirow{2}{*}{$\begin{array}{l}\text { VARIABLE } \\
\text { HAVE YOU SEEN SOMEONE... }\end{array}$} & \multicolumn{2}{|c|}{$\begin{array}{l}\text { DOES NOT } \\
\text { PARTICIPATE }\end{array}$} & \multicolumn{2}{|c|}{ VICTIM } & \multicolumn{2}{|c|}{ AGGRESSOR } & \multicolumn{2}{|c|}{$\begin{array}{c}\text { VICTIM- } \\
\text { AGGRESSOR }\end{array}$} & \multirow[b]{2}{*}{$\mathrm{K}$} & \multirow[b]{2}{*}{$p$} \\
\hline & $x$ & SD & $\mathrm{x}$ & SD & $x$ & SD & $x$ & SD & & \\
\hline $\begin{array}{l}\text { Aggress someone in the last } \\
\text { two weeks }\end{array}$ & $1.67^{\mathrm{a}}$ & 1.09 & $2.18^{b}$ & 1.27 & 1.50 & 0.89 & 1.89 & 1.20 & 14.549 & 0.002 \\
\hline Threaten verbally & $1.95^{\mathrm{a}}$ & 1.26 & $2.52^{b}$ & 1.42 & 2.28 & 1.49 & 2.74 & 1.63 & 14.154 & 0.003 \\
\hline Make jokes about peers & $2.83^{a}$ & 1.36 & $3.60^{b}$ & 1.37 & 3.22 & 1.29 & 3.37 & 1.30 & 18.828 & 0.001 \\
\hline Physically hit & $2.12^{\mathrm{a}}$ & 1.25 & $2.51^{b}$ & 1.35 & 2.28 & 1.17 & $2.68^{c}$ & 1.29 & 8.880 & 0.031 \\
\hline Call offensive names & $3.07^{\mathrm{a}}$ & 1.45 & $3.63^{b}$ & 1.32 & 3.59 & 1.39 & 3.79 & 1.32 & 13.080 & 0.004 \\
\hline Delete from the group & $2.28^{a}$ & 1.42 & $2.82^{b}$ & 1.43 & 2.75 & 1.54 & 3.00 & 1.53 & 12.905 & 0.005 \\
\hline Steal things from others & $1.42^{\mathrm{a}}$ & 0.90 & $1.94^{\mathrm{b}}$ & 1.25 & 2.06 & 1.43 & 1.89 & 1.20 & 20.230 & 0.001 \\
\hline $\begin{array}{l}\text { Do things on purpose to } \\
\text { hurt someone }\end{array}$ & $1.98^{a}$ & 1.16 & $2.79^{b}$ & 1.26 & $2.56^{c}$ & 1.22 & 2.74 & 1.33 & 33.407 & 0.001 \\
\hline $\begin{array}{l}\text { Damage the peers' clothes } \\
\text { on purpose }\end{array}$ & 1.25 & 0.74 & 1.48 & 1.00 & 1.34 & 0.83 & 1.74 & 1.24 & 9.121 & 0.028 \\
\hline $\begin{array}{l}\text { Hit or run after someone } \\
\text { in the way to school }\end{array}$ & $1.73^{\mathrm{a}}$ & 1.16 & $2.40^{\mathrm{b}}$ & 1.50 & 2.03 & 1.28 & 2.05 & 0.85 & 17.395 & 0.001 \\
\hline
\end{tabular}

X: media; SD: standard deviation; K: Kruskal Wallis; $p<0.05$.

\section{DISCUSSION}

The current research found that $59.4 \%$ of the participants were classified as spectators of bullying at school. This number was lower than the findings of Puhl and
King $^{9,15}$, Simão Freire and Ferreira ${ }^{8}$, which found 92.0\% $70.0 \%$ and $68.6 \%$ of students witnessing assaults, respectively. Despite the fact that this number is lower than those presented in the literature, it still represents the majority of the participants of the study. Even with data indicating the 
strong presence of spectators in schools, today many studies still overlook the participation of bystanders in bullying, although some data suggest most school-age children and adolescents assumed this role, ${ }^{8}$ which is fundamental to the understanding of this phenomenon. In addition, the witnesses are indirectly affected by situations of bullying, due to the emotional stress caused, as they may feel guilty for not helping the victim or ignored by the school authorities $^{6,13,16}$. All these data should be viewed with concern, as it suggests that bullying is already part of the routine of these young people regardless of grade attendance, age, gender, ethnic origin or social level ${ }^{8}$.

Regarding the type of bullying, the data from this study were consistent with the literature, indicating that the most frequent forms of violence observed by spectators were verbal assaults ${ }^{17-19}$. In addition, a greater participation was observed of girls as spectators of indirect bullying in the variable 'Delete Group', also supported by data in the literature, which indicate that girls are more involved in this type of violence ${ }^{17,20-25}$.

When asked what was the attitude taken by the students who reported ever having seen anyone beating or chasing a peer on the way to school, the data indicated that the majority of students, about $33.6 \%$, did nothing to stop such attacks. In addition to these, another 15.3\% approached to watch the aggression. These data are lower than those found by O'Connell, Pepler and Craig ${ }^{11}$, who found that in $54.0 \%$ of the time viewers watched such episodes passively and $21.0 \%$ played an active role of support and encouragement to the aggressor. To these authors and to Simon, Freire and Fernando, ${ }^{8}$ the fact that bystanders don't provide support to the victims reinforces the behaviour of the aggressors, because in the spaces where no effective interventions occur against bullying, the environment is 'contaminated' and all students, without exception, are negatively affected, experiencing feelings of fear and anxiety ${ }^{26}$.

On the other hand, it was found that one of the most prevalent attitudes of viewers is to 'support the assaulted' and to 'look for an adult'. These bystanders represented approximately $41.8 \%$ of participants, higher than the data found by O'Connell, Pepler and Craig ${ }^{11}$, in that $25.0 \%$ showed an intervening role in order to support or defend the victim. These data are seen as positive, because $t$, in general, the bystander deals with the violence daily and remains silent due to the fear of becoming the next victim of the aggressor ${ }^{27}$. In addition, the data of this study also indicated that the number of boys and girls who helped peers was quite similar, going against the literature that points to girls as being the ones to mainly assume this role $e^{4,28,29}$.

The data from this study also showed a strong association between being a spectator and other roles in bullying at school, especially with also being the aggressor. This is rather worrying, because being a spectator and also an aggressor, leads to the possibility of reinforcing this kind of violence. Twemlow, Fonagy and Sacco ${ }^{30}$ characterized this profile as 'Viewer aggressor', who supports the bullying offering a positive feedback, entering actively as an aggressor or supporting this fact through laughter and encouraging gestures. In addition, these students may become abusers as a way to preserve themselves, seeking to evade the condition of potential victim ${ }^{31}$. Other studies show a relationship in which the 'Spectator aggressor' may develop feelings of aversion towards school, frequency, avoidance, methods of blaming the victim and convictions in favour of the effectiveness of violence in conflict resolution. In the long run, the adverse effects of witnessing violence at school, can be as pernicious as the damage caused by concrete experiences of being subjected to violence experienced ${ }^{32,33}$.

It was also found that the victims were the ones that most experienced different situations of bullying in relation to non-participating students. This profile was also characterized by Twemlow, Fonagy and $\mathrm{Sacco}^{30}$, as 'passive bystander/victim', who simply stand aside quietly while watching, giving tacit consent, and may become part of the process of victimization. This data can be explained by the fact that often the victims see themselves as spectators of own aggressions suffered as well as being the most affected by this kind of behaviour. On the other hand, the aggressors have these attitudes as part of their normal routine, not considering so as situations of bullying. This identification is highly relevant to the understanding of this phenomenon, as environments with high levels of pro-bullying behaviours encourage aggressive teenagers to push others. Individuals with traits of high aggressiveness may be particularly sensitive to social rewards, increasing their bullying behaviour. On the other hand, anti-bullying behaviours predict a growth of the trajectory of intimidation would slow over time ${ }^{34,35}$.

The data of this study indicate a high number of bystanders of bullying in schools where most participants assumed that role. Similarly, strong associations were presented between spectator and other roles of participation in this phenomenon, mainly of being the aggressor. This reinforces the importance of bystanders in these assaults, not only because they represent most of the participants, but mainly because of the positive or negative reinforcement that they can contribute to these aggressive behaviours. So, identifying them and hearing them is crucial in the process of combating bullying, in view of the fact that this violence does not have social visibility among adults, resulting in valuable information being neglected that only their peers can provide. Thus, the incentive and encouragement offered to these students to denounce and fail to support the aggressors, as well as to defend the victims, is critical to reducing bullying and building a healthier and more favourable environment for the development of children and adolescents.

A limitation of this study is that the cross-sectional design prevents the realization of inferences about the direction of the relationships identified, not allowing the establishment of causalities. In addition, another limitation was the choice for convenience of schools participating in the study, which prevents the data from being generalized to all children and adolescents as a whole. Future research should adopt a longitudinal design and a probability sampling, because this will make it possible to monitor changes over time in order to identify the effects of viewer involvement exercised in other roles in bullying, identifying cause-and-effect relationships and the profile of children and teenagers in general. This study stress- 
es the importance of further studies aimed at addressing these limitations so that they can clarify the relationship between these variables, in order to obtain more accurate data that can support prevention efforts and the addressing of this problem at school.

Despite such limitations, the results presented in this study intensify the relevance related to the theme, sorting the bullying phenomenon on the quality of the 'question problem' in the field of public health, due to the importance that spectators have in the prevalence of this behaviour in the school environment, often reproducing what is assisted and causing damage in the affective, social and development of inter-and intra-personal relationships among children and adolescents. Early identification of the participants of bullying and how they behave, regardless of their role, contributes to the engagement of intervention programmes that provide prevention strategies related to this phenomenon, with the involvement of both public social policies, such as the integration of a pedagogical team, parents and teachers, in order to establish children's and adolescents' healthy growth and a mutual respect for themselves and others.

The results of this study still present some convergences and divergences in relation to other researchers of this theme. One of the convergences seems to be a con- sensus in the literature that most children and adolescents in schools take on the role of spectator when faced with bullying at school. In addition, verbal assaults are the most frequent incidents observed by spectators; that girls are more involved in bullying and indirect associations between the role of the spectator and other roles in bullying, for example, 'spectator aggressor' and 'passive bystander/ victim' have already been established by the literature. On the other hand, the differences found in this study were mainly about the attitudes taken by spectators in situations of violence. In this study, the participants demonstrated a position more in favour of the victim and showed less support to the perpetrators, as well as there being an equivalent number of boys and girls who have shown support to peers, when compared to the literature.

However, regardless of the role, involvement in bullying can provide students experience as being a spectator, while non-participation in this phenomenon step away children and adolescents from situations of violence. So, bullying should be seen as a complex phenomenon, which affects all involved and needs to be prevented and combated in all spheres. In this way, more studies are suggested aimed at understanding the profile of these participants, broadening and forcing these findings, which may then assist them in the process of combating bullying at school.

\section{REFERENCES}

1. Magklara K, Skapinakis P, Gkatsa T, Bellos S, Araya R, Stylianidis S, et al. Bullying behaviour in schools, socioeconomic position and psychiatric morbidity: a cross-sectional study in late adolescents in Greece. Child Adolesc Psychiatry Ment Health. 2012;6:8. DOI: http://dx.doi.org/10.1186/1753-2000-6-8

2. Chui WH, chan HCO. Self-control, School Bullying Perpetration, and victimization among macanese adolescents. J Child Fam Stud. 2015;24:1751. DOI: http://dx.doi.org/10.1007/s10826-014-9979-3

3. Tani F, Greenman P, Schneider B, Fregoso M. Bullying and the big five: a study of childhood personality and participant roles in bullying incidents. School Psychol Int. 2003;24(2):131-46. DOI: http://dx.doi.org/11 $0.1177 / 0143034303024002001$

4. Raimundo R, Seixas S. Comportamentos de bullying no $1^{\circ}$ ciclo: estudo de caso numa escola de Lisboa. Interacções. 2009(13):164-86.

5.Cranham J, Carroll A. Dynamics within the bully/victim paradigm: a qualitative analysis. Educ Psychol Practice. 2003;19(2):113-32. DOI: http://dx.doi.org/10.1080/02667360303235

6. Tsang SK, Hui EK, Law BC. Bystander position taking in school bullying: the role of positive identity, self-efficacy, and self-determination. Scientific World J. 2011;11:2278-86. DOI: http://dx.doi.org/10.1100/2011/531474

7. Hawkins D, Pepler D, Craig W. Naturalistic observations of peer interventions in bullying. Social Dev. 2001;10(4):512-27. DOI: http://dx.doi.org/10.1111/1467-9507.00178

8. Simão A, Freire I, Ferreira A. Maus-tratos entre pares na escola: um estudo contextualizado. Actas do Congresso Ibero-Americano sobre Violências nas Escolas. Brasília: UNESCO; 2004.

9. Fischer RM, Lorenzi G, Pedreira L, Bose M, Fante C, Berthoud C. Bullying escolar no Brasil: relatório final. São Paulo: 2010.

10. Stueve A, Dash K, O'Donnell L, Tehranifar P, Wilson-Simmons R, Slaby RG, et al. Rethinking the bystander role in school violence prevention. Health Promot Pract. 2006;7(1):117-24. DOI: http://dx.doi. org/10.1177/1524839905278454

11. O'Connell P, Pepler D, Craig W. Peer involvement in bullying: insights and challenges for intervention. J Adolesc. 1999;22(4):437-52. DOI: http://dx.doi.org/10.1006/jado.1999.0238

12. Freire I, Simão A, Ferreira A. O estudo da violência entre pares no $3^{\circ}$ ciclo do ensino básico: um questionário aferido para a população escolar portuguesa. Rev Port Educação. 2006;19(2):157-83.

13. Kohut $\mathrm{M}$. The complete guide to understanding, controlling, and stopping Bullies \& Bullying: a complete guide for teachers \& parents. Ocala: Atlantic; 2007.

14. Olweus D. The Olweus Bully/Victim Questionnaire. Bergen: Mimeo; 1986.

15. Puhl RM, King KM. Weight discrimination and bullying. Best Pract Res Clin Endocrinol Metab. 2013;27(2):117-27. DOI: http://dx.doi.org/10.1016/j.beem.2012.12.002 
16. Rigby K. Peer victimisation at school and the health of secondary school students. $\mathrm{Br} \mathrm{J}$ Educ Psychol. 1999;69 (1):95-104. DOI: http://dx.doi.org/10.1348/000709999157590

17. Wang J, lannotti RJ, Nansel TR. School bullying among adolescents in the United States: physical, verbal, relational, and cyber. J Adolesc Health. 2009;45(4):368-75. DOI: http://dx.doi.org/1016/j.jadohealth.2009.03.021

18. Vieno A, Gini G, Santinello M. Different forms of bullying and their association to smoking and drinking behavior in Italian adolescents. J Sch Health. 2011;81(7):393-9. DOI: http://dx.doi.org/10.1111/j.17461561.2011.00607.x

19. Chang FC, Lee CM, Chiu CH, Hsi WY, Huang TF, Pan YC. Relationships among cyberbullying, school bullying, and mental health in Taiwanese adolescents. J Sch Health. 2013;83(6):454-62. DOI: http://dx.doi. org/10.1111/josh.12050

20. Bandura A, Ross D, Ross SA. Transmission of aggression through imitation of aggressive models. J Abnorm Soc Psychol. 1961;63:575-82. DOI: http://dx.doi.org/10.1037/h0045925

21. Cairns R, Cairns B, Neckerman H, Ferguson L, Gariépy J. Growth and aggression: I. Childhood to early adolescence. Dev Psychol. 1989;25:320-30. DOI: http://dx.doi.org/10.1037/0012-1649.25.2.320

22. Crick NR, Grotpeter JK. Relational aggression, gender, and social-psychological adjustment. Child Dev. 1995;66(3):710-22. DOI: http://dx.doi.org/10.2307/1131945

23. Brannon L. Gender: psychological perspectives. Boston: Allyn and Bacon; 1999.

24. Smith P. Bullying: Recent Developments. Child Adolesc Mental Health. 2004;9(3):98-103. DOI: http:// dx.doi.org/10.1111/j.1475-3588.2004.00089.x

25. Frisén A, Jonsson AK, Persson C. Adolescents' perception of bullying: who is the victim? Who is the bully? What can be done to stop bullying? Adolescence. 2007;42(168):749-61.

26. Rocha MO, Costa CLNA, Passos Neto IF. Bullying e o papel da sociedade. Cad Graduação: Ciênc Hum Sociais. 2013;1(16):191-99.

27. Levandoski G, Cardoso F. Imagem corporal e status social de estudantes brasileiros envolvidos em bullying. Rev Latinoam Psicol. 2013;45(1):135-45.

28. Rigby K, Slee PT. Bullying among Australian school children: reported behavior and attitudes toward victims. J Soc Psychol. 1991;131(5):615-27. DOI: http://dx.doi.org/10.1080/00224545.1991.9924646

29. Salmivalli C, Lagerspetz K, Björkqvist K, Kaukiainen A, Österman K. Bullying as a group process: participant roles and their relations to socialstatus within the group. Aggressive Behavior. 1996;22:1-15. DOI: http://dx.doi.org/10.1002/(SICI)1098-2337(1996)22:1<1::AID-AB1>3.0.CO;2-T

30. Twemlow SW, Fonagy P, Sacco FC. The role of the bystander in the social architecture of bullying and violence in schools and communities. Ann N Y Acad Sci. 2004;1036:215-32. DOI: http://dx.doi.org/10.1196/ annals.1330.014

31. Janosz M, Archambault I, Pagani LS, Pascal S, Morin AJ, Bowen F. Are there detrimental effects of witnessing school violence in early adolescence? J Adolesc Health. 2008;43(6):600-8. DOI: http://dx.doi. org/10.1016/j.jadohealth.2008.04.011

32. Margolin G, Gordis EB. Children's exposure to violence in the family and community. Curr Direct Psychol Sci. 2004;13(4):152-5. DOI: http://dx.doi.org/10.1111/j.0963-7214.2004.00296.x

33. Mrug S, Windle M. Bidirectional influences of violence exposure and adjustment in early adolescence: Externalizing behaviors and school connectedness. J Abnorm Child Psychol. 2009;37(5):611-23. DOI: http:// dx.doi.org/10.1007/s10802-009-9304-6

34. Salmivalli C, Kärnä A, Poskiparta E. From peer putdowns to peer support: a theoretical model and how it translated into a national anti-bullying program. In: Jimerson S, Swearer S, Espelage D. Handbook of bullying in schools: An international perspective. New York: Guilford; 2010; p. 441-54.

35. Nocentini A, Menesini E, Salmivalli C. Level and change of bullying behavior during high school: a multilevel growth curve analysis. J Adolesc. 2013;36(3):495-505. DOI: http://dx.doi.org/10.1016/j.adolescence.2013.02.004

This article is distributed under the terms of the Creative Commons Attribution 4.0 International License (http://creativecommons.org/licenses/by/4.0/), which permits unrestricted use, distribution, and reproduction in any medium, provided you give appropriate credit to the original author(s) and the source, provide a link to the Creative Commons license, and indicate if changes were made. The Creative Commons Public Domain Dedication waiver (http://creativecommons.org/publicdomain/zero/1.0/) applies to the data made available in this article, unless otherwise stated. 


\section{Resumo:}

Introdução: O bullying escolar é caracterizado pela repetitividade das agressões e pela intencionalidade em se ferir ou causar sofrimento ao outro. Os espectadores deste fenômeno tendem a ser os principais responsáveis pelo curso que o bullying tomará, bem como quais serão seus respectivos resultados.

Objetivo: Analisar a associação entre o papel do espectador com os outros possíveis papéis de participação no bullying.

Método: Participaram deste estudo 409 crianças e adolescentes do $3^{\circ}$ ao $7^{\circ} \mathrm{ano}$, com média de idade de 11 anos (SD = 1,61), matriculadas em duas escolas públicas municipais da Grande Florianópolis. Os instrumentos utilizados foram: uma das escalas do Questionário para o Estudo da Violência Entre Pares, para identificar os espectadores; Questionário de Olweus, para descrever os possíveis papéis de participação no bullying.

Resultados: Verificou-se que a maioria dos participantes assumia o papel de espectador no bullying escolar. Entretanto, não foi encontrada associação em relação ao sexo e ser espectador. Por outro lado, encontrou-se uma forte associação entre ser espectador e os outros papéis assumidos no bullying, principalmente em relação aos agressores.

Conclusões: Esses resultados reforçam a importância dos espectadores nessas agressões, não apenas por representarem a maior parte dos participantes, mas principalmente pelo reforço positivo ou negativo que eles podem oferecer a esses comportamentos agressivos. Assim, o incentivo e o encorajamento destes alunos para denunciarem e reprovarem os agressores, bem como defenderem as vítimas, é fundamental para a redução do bullying escolar.

Palavras-chave: bullying, espectadores, vulnerabilidade. 